\title{
Fokl vitamin D receptor polymorphism as a protective factor in intrahepatic cholestasis of pregnancy
}

\author{
Hubert Wolski ${ }^{1,2}{ }^{\oplus}$, Grazyna Kurzawinska ${ }^{1,3}{ }^{\oplus}$, Marcin Ozarowski ${ }^{4}$,

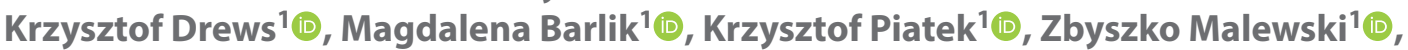 \\ Aleksandra E. Mrozikiewicz ${ }^{5}{ }^{\circledR}$, Justyna Magielda-Stola' ${ }^{1}$, Dorota Kolanowska' ${ }^{1}$, \\ Marlena Wolek ${ }^{6}$, Agnieszka Seremak-Mrozikiewicz ${ }^{1,3,7}$ \\ ${ }^{1}$ Division of Perinatology and Women's Disease, Poznan University of Medical Sciences, Poznan, Poland \\ ${ }^{2}$ Division of Obstetrics and Gynecology, Poviat Hospital, Zakopane, Poland \\ ${ }^{3}$ Laboratory of Molecular Biology in Division of Perinatology and Women's Diseases, \\ Poznan University of Medical Sciences, Poznan, Poland \\ ${ }^{4}$ Department of Biotechnology, Institute of Natural Fibres and Medicinal Plants, Poznan, Poland \\ ${ }^{5}$ Division of Infertility and Reproductive Endocrinology, Poznan University of Medical Sciences, Poznan, Poland \\ ${ }^{6}$ Department for Research on Stem Cells and Regenerative Medicine, \\ Institute of Natural Fibres and Medicinal Plants, Plewiska/Poznan, Poland \\ ${ }^{7}$ Department of Pharmacology and Phytochemistry, Institute of Natural Fibres and Medicinal Plants, Plewiska/Poznan, Poland
}

\begin{abstract}
Objectives: Intrahepatic cholestasis in pregnancy (ICP) is a pregnancy-specific liver disorder. Its etiology is not fully understood. Increasing evidence indicates the important role of vitamin $D$ and the vitamin D receptor (VDR) in this disorder. The presence of polymorphic variants in the VDR gene could influence its activity and susceptibility to ICP development. The goal of the study was to investigate the role of four genetic polymorphisms of the VDR gene - Fok (rs731236), Bsm (rs1544410), Apa (rs7975232), and Taq (rs731236) — in the etiology of ICP in Polish women.

Material and methods: Ninety-eight women with confirmed ICP and 215 healthy pregnant women as a control group were recruited to the study. We examined four SNPs of the VDR gene: Bsml (rs7975232), Taql (rs1544410), Apal (rs228570), Fokl (rs731236). Genotyping was performed using the PCR/RFLP method.

Results: We observed higher frequency (borderline significant) of the Ff-ff genotypes containing at least one mutated allele of the VDR Fokl polymorphism in the control group compared to the ICP group $(p=0.045, \mathrm{OR}=1.71,95 \% \mathrm{Cl} 1.01-2.88)$. The frequency of the mutated fallele was slightly higher in controls (49.1\%) than in the ICP group (43.4\%) $(\mathrm{OR}=1.26,95 \%$ $\mathrm{Cl} 0.90-1.77)$, but the difference was not statistically significant $(p=0.196)$.

Conclusions: Our results showed that the maternal VDR Fokl polymorphism could play a protective role in ICP development and probably modulate the risk of ICP occurrence in pregnant women in the Polish population. In the future, to confirm these observations, research in larger, ethnically stratified and clinically analyzed groups is necessary.

Key words: intrahepatic cholestasis in pregnancy; vitamin D receptor; genetic polymorphism
\end{abstract}

Ginekologia Polska 2020; 91, 12: 719-725

\section{INTRODUCTION}

Intrahepatic cholestasis of pregnancy (ICP), affecting $0.2-2 \%$ of pregnancies, is a pregnancy-specific liver disorder that typically presents in the third trimester. It is characterized by pruritus associated with elevated serum bile acids and/or aminotransferase levels. The etiology of ICP is complex and still not fully understood. Evidence suggests that it is caused by a combination of hormonal changes, genetic variations, environmental factors and nutritional deficien- cies [1]. Also seasonal variation in the frequency of ICP has been observed with a higher prevalence noted in winter months in Scandinavia, Chile and Portugal [2, 3].

Vitamin D (VD) has many important biologic functions, including mineral balance and skeletal maintenance, control of cell proliferation, regulation of differentiation, inhibition of tumor growth and induction of apoptosis $[4,5]$. The expression of more than 2000 genes (3\% of the human genome) is regulated by the vitamin D signaling pathway $[6,7]$. 
Maternal vitamin D deficiency (VDD) during pregnancy is a global concern that may have important implications for offspring metabolic health. There is increasing evidence that vitamin D plays a role in hepatobiliary homeostasis and in various liver diseases, including ICP [8, 9].

The role of vitamin $D$ in fetal development has been demonstrated, especially in early pregnancy, in skeletal development, and the maturity of the immune system $[10,11]$. Vitamin $D$ deficiency has been related to a higher incidence of preeclampsia, fetal hypotrophy, gestational diabetes, preterm labor and bacterial vaginosis in pregnant women [12-16]. Some reports indicate a possible relationship between vitamin $D$ and intrahepatic cholestasis in pregnant women $[8,10]$. In addition, it has been proven that VDR is expressed in different parts of the uteroplacental unit and performs different functions in physiological pregnancy. It regulates implantation, affects hormone secretion, and modulates the immunological functions of the placenta, especially in early pregnancy $[17,18]$.

The vitamin $D$ receptor (VDR), which maps on chromosome 12q12-q14, a member of the nuclear hormone receptor superfamily of ligand-inducible transcription factors, is one of the candidate genes of vitamin D deficiency. Polymorphism of the VDR receptor gene may reduce the response to vitamin $D$ and significantly change the expression of the genes regulated by this vitamin [19]. Currently, more than 200 genes modulated by VDR receptors are known, which indicates the pleiotropic effect of vitamin D. The VDR receptor, activated by $1.25-(\mathrm{OH}) \mathrm{D}$, together with the retinoic acid receptor (RXR) forms a heterodimer that acts as a transcription factor. The VDR-RXR heterodimer binds to the promoter of the selected genes, which enables the initiation/inhibition of the transcription process [20]. Increasing evidence shows the role of vitamin D and the VDR receptor in intrahepatic hemostasis, by inhibiting expression of the cholesterol 7alpha-hydroxylase gene (CYP7A1) and therefore modulating the synthesis of bile acids in hepatocytes, thereby protecting liver cells in humans. One of the possible pathways affecting the modulation of VDR activity and in the same way susceptibility to disease occurrence, is the presence of genetic variants in its gene [21,22].

Therefore, the purpose of this study was to investigate the effect of four genetic polymorphisms of the VDR gene - Fok (rs731236), Bsm (rs1544410), Apa (rs7975232), and Taq (rs731236) - on the etiology of ICP in Polish women.

\section{MATERIALS AND METHODS}

\section{Subjects}

A total of 313 women were recruited to the study: 98 women with confirmed ICP and 215 randomly selected healthy pregnant women who comprised the control group. The research was performed in the years 2013-2017, in two medical centers: the Division of Perinatology and Women's Diseases of Poznan University of Medical Sciences in Poznan and the Department of Gynecology and Obstetrics with Gynecological Oncology Subdivision of Regional Hospital in Zielona Góra. The study was approved by the Poznan University of Medical Sciences Bioethics Committee, Poland, and informed consent was obtained from all the participants. All women included in our study were of Polish ancestry.

In the course of the study the detailed demographic profiles and clinical characteristics were collected from all patients. ICP was diagnosed based on clinical and laboratory criteria: characteristic pruritus without rashes and/or increase in serum bile acids (TBA) $\geq 10 \mu \mathrm{mol} / \mathrm{L}$ in fasting state, increase level of alanine aminotransferase (ALT) $\geq 33 \mathrm{IU} / \mathrm{L}$ and aspartate aminotransferase (AST) $\geq 32 \mathrm{IU} / \mathrm{L}$. The women with ICP were observed within 2-3 weeks after delivery when the symptoms had resolved. We excluded women with any causes of hepatic impairment, such as infection with hepatitis viruses (HAV, HBV and HCV), autoimmune diseases, excessive alcohol consumption, HIV infection, biliary obstruction, and other liver and dermatological diseases that cause skin itching. We also excluded those with multiple pregnancies, chromosomal abnormalities, fetal anomalies, maternal infections, pregnancies complicated by thyroid disease, hypertension, and diabetes mellitus, from the study groups. Blood for laboratory tests was secured in all women with ICP before initiating treatment.

\section{Genotyping}

We examined four SNPs (rs7975232, rs1544410, rs228570, rs731236) in the VDR gene, and all of the SNPs had minor allele frequencies (MAF) greater than $5 \%$. Traditionally these allelic variants have been designated by the upper and lower case of the starting initial of the named loci, e.g. Bsml (b and B), Taql (t and T), Apal ( $\mathrm{a}$ and $\mathrm{A}$ ) and Fokl ( $\mathrm{f}$ and F). Genomic DNA was isolated from whole blood collected in K3-EDTA tubes using the Qiagen DNA Blood Mini Kit (Qiagen, Germany) according to the manufacturer's instructions and was stored at minus $80^{\circ} \mathrm{C}$. A NanoDrop 2000 spectrophotometer (Wilmington, DE, USA) was used to evaluate the quality and quantity of DNA. Genotyping was performed in the Molecular Biology Laboratory of Poznan Medical Science University using the PCR/RFLP method as described previously [23-25]. Products were analyzed by electrophoresis on 2.5\% agarose gel with Midori Green Advanced DNA Stain (Nippon Genetics, Europe GmbH) (Tab. 1).

\section{Statistical analysis}

Statistical analyses were conducted using $\mathrm{R}$ version 3.6.0 [26]. For each SNP, the Hardy-Weinberg equilibrium (HWE) was assessed using Pearson's goodness-of-fit $X^{2}$ statis- 


\begin{tabular}{l|l|l|l|l|}
\hline \multicolumn{4}{|l}{ Table 1. SNPs genotyped in VDR gene } \\
$\begin{array}{l}\text { Reference } \\
\text { SNP ID }\end{array}$ & rs2228570 & rs1544410 & rs7975232 & rs731236 \\
\hline $\begin{array}{l}\text { Traditional } \\
\text { Name }\end{array}$ & Fokl & Bsml & Apal & Taql \\
\hline Localization & Exon 2 & Intron 8 & Intron 8 & Exon 9 \\
\hline $\begin{array}{l}\text { Allele } \\
\text { (Traditional }\end{array}$ & C/T (F/f) & G/A (b/B) & A/C (A/a) & T/C (T/t) \\
$\begin{array}{l}\text { Variant) } \\
\text { Amino Acid }\end{array}$ & Met-Thr & Non-coding & Non-coding & Ile-lle \\
\hline
\end{tabular}

\begin{tabular}{|c|c|c|c|}
\hline $\begin{array}{l}\text { Parameters at } \\
\text { mothers }\end{array}$ & $\begin{array}{l}\text { ICP } \\
n=98\end{array}$ & $\begin{array}{l}\text { Controls } \\
n=215\end{array}$ & $\mathbf{p}$ \\
\hline $\begin{array}{l}\text { Maternal age } \\
\text { [years] }\end{array}$ & $30.40 \pm 4.38$ & $30.66 \pm 4.66$ & 0.65 \\
\hline $\begin{array}{l}\text { Gestational age at } \\
\text { delivery [weeks] }\end{array}$ & $36.87 \pm 2.73$ & $39.03 \pm 1.23$ & $<0.0001$ \\
\hline $\begin{array}{l}\text { Systolic blood } \\
\text { pressure [mmHg] }\end{array}$ & $110.13 \pm 10.71$ & $108.65 \pm 10.23$ & 0.26 \\
\hline $\begin{array}{l}\text { Diastolic blood } \\
\text { pressure [mmHg] }\end{array}$ & $67.57 \pm 8.89$ & $66.42 \pm 7.83$ & 0.27 \\
\hline $\begin{array}{l}\text { Before pregnancy } \\
\text { BMI }\left[\mathrm{kg} / \mathrm{m}^{2}\right]\end{array}$ & $22.93 \pm 4.53$ & $21.89 \pm 3.59$ & 0.04 \\
\hline $\begin{array}{l}\text { Total bile acids } \\
\text { [umol/L] }\end{array}$ & $20.94 \pm 27.05$ & $2.80 \pm 2.10$ & $<0.0001$ \\
\hline $\begin{array}{l}\text { Aspartate } \\
\text { aminotransferase } \\
{[\text { [IU/L] AST }}\end{array}$ & $255.51 \pm 230.50$ & N.A. & - \\
\hline $\begin{array}{l}\text { Alanine amino } \\
\text { transferase [IU/L] } \\
\text { ALT }\end{array}$ & $155.33 \pm 142.58$ & N.A. & - \\
\hline Placenta weight [g] & $585.90 \pm 154.55$ & $621.18 \pm 112.04$ & 0.04 \\
\hline $\begin{array}{l}\text { Caesarean section, } \\
\mathrm{n}(\%)\end{array}$ & 44 (45.83\%) & $71(33.02 \%)$ & 0.03 \\
\hline Primipara, n (\%) & $43(44.79 \%)$ & $83(38.60 \%)$ & 0.31 \\
\hline \multicolumn{4}{|l|}{$\begin{array}{l}\text { Parameters at } \\
\text { neonates }\end{array}$} \\
\hline $\begin{array}{l}\text { Neonate birth } \\
\text { weight [g] }\end{array}$ & $3094.09 \pm 631.30$ & $3418.37 \pm 434.21$ & $<0.0001$ \\
\hline $\begin{array}{l}\text { Apgar score at } \\
5 \mathrm{~min}\end{array}$ & $9.74 \pm 0.74$ & $9.97 \pm 0.22$ & $<0.0001$ \\
\hline $\begin{array}{l}\text { Baby sex (son), } \\
\mathrm{n}(\%)\end{array}$ & 49 (51.04\%) & $125(58.14 \%)$ & 0.24 \\
\hline
\end{tabular}

N.A. - not accomplished

tic. Continuous variables were expressed as mean \pm standard deviation whereas categorical variables were expressed as numbers or percentages. Significant differences between two groups were analyzed by Student's $t$-test. Differences in allele and genotype frequencies between the case and control subjects, odds ratios (ORs) and associated 95\% confidence intervals ( $95 \% \mathrm{Cls}$ ) were evaluated using the SNPassoc package for R [27]. The data were analyzed using codominant, recessive and dominant inheritance models. Haplotype analysis was performed using the Haplo. stats $R$ package [28]. Two-tailed $p$ values less than 0.05 were accepted to be statistically significant.

\section{RESULTS}

\section{Demographic and clinical characteristics of subjects}

In our study the mean age of cases and controls was $30.40 \pm 4.38$ and $30.66 \pm 4.66$ years, respectively (non-significant). ICP women delivered at $36.87 \pm 2.73$ weeks, whereas controls delivered at term $(39.3 \pm 1.23$ weeks $)$ $(p<0.0001)$. Significant differences in total bile acids $(20.94 \pm 27.05$ vs $2.80 \pm 2.10 \mu \mathrm{mol} / \mathrm{L}, \mathrm{p}<0.0001)$, neonate birth weight $(3094.09 \pm 631.30 \mathrm{~g}$ vs $3418.37 \pm 434.21 \mathrm{~g}, \mathrm{p}<0.0001)$, and neonate Apgar score $(9.74 \pm 0.74$ vs $9.97 \pm 0.22$, $\mathrm{p}<0.0001$ ) were observed. The demographic and clinical characteristics of ICP patients and controls are shown in Table 2.

\section{Association of VDR gene polymorphisms with risk of ICP}

We explored the VDR gene polymorphisms with risk of ICP under codominant, dominant and recessive model, and there were no significant differences in the codominant model (rs2228570, rs1544410, rs797523 and rs731236, all results show $\mathrm{p}>0.05$ ).

The most interesting observation was the higher frequency of the Ff-ff genotypes containing at least one mutated allele of the VDR Fokl polymorphism in the control group compared to the ICP group with the difference of borderline statistical significance $(p=0.045, O R=1.71,95 \%$ $\mathrm{Cl}$ 1.01-2.88). The frequency of the mutated $f$ allele was slightly higher in controls (49.1\%) than in the ICP group (43.4\%) (OR $=1.26,95 \% \mathrm{Cl} 0.90-1.77)$, but the difference was not statistically significant $(\mathrm{p}=0.196)$.

For both VDR Bsml and VDR Taq/ polymorphisms a slightly higher frequency of genotypes containing at least one mutated allele in the ICP group was found, but without statistical significance. There was also no contribution of the VDR Apal polymorphism to ICP etiology. Genotype analysis of the VDR polymorphisms did not show any significant deviation from Hardy-Weinberg equilibrium in ICP and control groups. The allele and genotype frequencies in ICP women and healthy controls are presented in Table 3.

\section{Haplotype analyses}

For four-locus haplotypes six main variants (fbaT, FBAt, fBAt, fbAT, FbaT and FbAT) were constructed for rs2228570, 


\begin{tabular}{|c|c|c|c|c|c|c|}
\hline & & ICP $n=98(\%)$ & Control $n=215(\%)$ & OR & $95 \% \mathrm{Cl}$ & $\mathbf{p}$ \\
\hline \multirow{5}{*}{ rs2228570 (Fokl) } & CC (FF) & $34(34.7)$ & $51(23.7)$ & 1.00 & \multirow{3}{*}{$\begin{array}{l}1.04-3.17 \\
0.76-2.92\end{array}$} & \multirow{3}{*}{0.112} \\
\hline & $\mathrm{CT}(\mathrm{Ff})$ & $43(43.9)$ & $117(54.4)$ & 1.81 & & \\
\hline & $\mathrm{TT}$ (ff) & $21(21.4)$ & $47(21.9)$ & 1.49 & & \\
\hline & CC vs CT-TT & $64(65.3)$ & 164 (76.3) & 1.71 & $1.01-2.88$ & 0.045 \\
\hline & CC-TC vs TT & 77 (78.6) & 168 (78.1) & 1.03 & $0.57-1.83$ & 0.931 \\
\hline \multirow{2}{*}{ Allele } & $C(F)$ & $111(56.6)$ & $219(50.9)$ & 1.00 & \multirow[b]{2}{*}{$0.90-1.77$} & \multirow{2}{*}{0.196} \\
\hline & $T(f)$ & $85(43.4)$ & 211 (49.1) & 1.26 & & \\
\hline \multirow{5}{*}{ rs1544410 (Bsml) } & $\mathrm{GG}(\mathrm{bb})$ & 31 (31.6) & $91(42.3)$ & 1.00 & \multirow{3}{*}{$\begin{array}{l}0.37-1.09 \\
0.30-1.22\end{array}$} & \multirow{3}{*}{0.191} \\
\hline & $\mathrm{GA}(\mathrm{bB})$ & $48(49.0)$ & $90(41.9)$ & 0.64 & & \\
\hline & $\mathrm{AA}(\mathrm{BB})$ & $19(19.4)$ & $34(15.8)$ & 0.61 & & \\
\hline & GG vs GA-AA & $67(68.4)$ & $124(57.7)$ & 0.63 & $0.38-1.04$ & 0.070 \\
\hline & GG-GA vs $A A$ & $79(80.6)$ & $181(84.2)$ & 0.78 & $0.42-1.45$ & 0.439 \\
\hline \multirow{2}{*}{ Allele } & $\mathrm{G}(\mathrm{b})$ & $110(56.1)$ & $272(63.3)$ & 1.00 & \multirow[b]{2}{*}{$0.53-1.05$} & \multirow{2}{*}{0.094} \\
\hline & $A(B)$ & $86(43.9)$ & $158(36.7)$ & 0.74 & & \\
\hline \multirow{5}{*}{ rs797523 (Apal) } & $A A(A A)$ & $26(26.5)$ & $50(23.3)$ & 1.00 & \multirow{3}{*}{$\begin{array}{l}0.66-2.09 \\
0.62-2.48\end{array}$} & \multirow{3}{*}{0.811} \\
\hline & $A C(A a)$ & $51(52.0)$ & $115(53.5)$ & 1.17 & & \\
\hline & CC (aa) & $21(21.4)$ & $50(23.3)$ & 1.24 & & \\
\hline & $A A$ vs $A C-C C$ & $72(73.5)$ & $165(76.7)$ & 1.19 & $0.69-2.06$ & 0.533 \\
\hline & $\mathrm{AA}-\mathrm{AC}$ vs $\mathrm{CC}$ & 77 (78.6) & $165(76.7)$ & 1.11 & $0.62-1.98$ & 0.719 \\
\hline \multirow{2}{*}{ Allele } & $A(A)$ & $103(52.6)$ & $215(50.0)$ & 1.00 & \multirow[b]{2}{*}{$0.79-1.55$} & \multirow{2}{*}{0.605} \\
\hline & $C(a)$ & $93(47.4)$ & $215(50.0)$ & 1.11 & & \\
\hline \multirow{5}{*}{ rs731236 (Taql) } & $\mathrm{TT}(\mathrm{TT})$ & $32(32.7)$ & $93(43.3)$ & 1.00 & \multirow{3}{*}{$\begin{array}{l}0.36-1.01 \\
0.37-1.76\end{array}$} & \multirow{3}{*}{0.150} \\
\hline & $\mathrm{TC}(\mathrm{Tt})$ & $54(55.1)$ & 94 (43.7) & 0.60 & & \\
\hline & $\mathrm{CC}(\mathrm{tt})$ & $12(12.2)$ & $28(13.0)$ & 0.80 & & \\
\hline & TT vs TC-CC & $66(67.3)$ & $122(56.7)$ & 0.64 & $0.39-1.05$ & 0.074 \\
\hline & TT-TC vs CC & $86(87.8)$ & $187(87.0)$ & 1.07 & $0.52-2.21$ & 0.848 \\
\hline \multirow{2}{*}{ Allele } & $\mathrm{T}(\mathrm{T})$ & $118(60.2)$ & $280(65.1)$ & 1.00 & \multirow[b]{2}{*}{$0.57-1.15$} & \multirow{2}{*}{0.245} \\
\hline & $C(\mathrm{t})$ & $78(39.8)$ & $150(34.9)$ & 0.81 & & \\
\hline
\end{tabular}

rs1544410, rs797523 and rs731236 polymorphisms of the VDR gene. The most frequent variant in ICP patients was FBAt haplotype (28.5\%), whereas the estimated prevalence of this haplotype in controls was only $23.9 \%$. When looking at the three-locus haplotypes (Bsml, Apal, and Taql), there were also no apparent associations with ICP. Our results indicate that the most common haplotype for the VDR gene is baT ( $47.4 \%$ in ICP women and $49.3 \%$ in controls). There were no significant differences in the frequency of investigated haplotype variants between ICP women and healthy controls (Tab. 4).

\section{DISCUSSION}

Numerous studies have analyzed the influence of vitamin D disturbed metabolism on pregnancy outcome. Several studies analyzed vitamin D levels in groups of women with ICP.
In the Swedish population, reduced VD levels were observed in women with ICP, regardless of the level of bile acids (22 ICP women, 11 healthy pregnant women). In this study statistically significantly lower VD in serum from the ICP group (76.4 \pm 23.1 vs $112.0 \pm 40 \mathrm{ng} / \mathrm{L}$ in controls, $\mathrm{p}=0.0041$ ) was observed [8].

Also in the study performed by Gençosmanoğlu Türkmen et al. [9] (40 pregnant women with ICP and 40 healthy pregnant women) vitamin D levels were significantly lower in women with ICP compared to the controls ( $8.6 \pm 4.9$ vs $11.3 \pm 6.1 \mathrm{ng} / \mathrm{mL}$ in controls, $\mathrm{p}=0.033$ ). In addition, the authors observed lower VD levels in serum from patients with the severe form of ICP $(6.9 \pm 2.1$ vs $10.3 \pm 6.2 \mathrm{ng} / \mathrm{mL}$ in severe ICP, $p=0.029$ ) [9].

Although it is known that etiology of ICP is multifactorial, including the genetic basis of the disease, there is not much 
Table 4. Haplotype analysis results among SNPs in VDR locus

\begin{tabular}{|l|l|l|l|l|}
\hline Haplotype & ICP (freq) & Control (freq) & OR (95\% Cl) & p value \\
\hline FBAt & $56(0.285)$ & $103(0.239)$ & $1.269(0.867-1.858)$ & 0.218 \\
\hline FbaT & $48(0.244)$ & $93(0.216)$ & $1.175(0.789-1.75)$ & 0.426 \\
\hline fbaT & $45(0.229)$ & $119(0.276)$ & $0.778(0.525-1.155)$ & 0.213 \\
\hline fBAt & $22(0.112)$ & $43(0.100)$ & $1.137(0.66-1.96)$ & 0.641 \\
\hline fbAT & $12(0.061)$ & $42(0.097)$ & $0.602(0.309-1.171)$ & 0.131 \\
\hline FbAT & $5(0.025)$ & $14(0.032)$ & $0.777(0.276-2.19)$ & 0.633 \\
\hline baT & $93(0.474)$ & $212(0.493)$ & $0.928(0.662-1.302)$ & 0.667 \\
\hline BAt & $78(0.397)$ & $146(0.339)$ & $1.285(0.907-1.822)$ & 0.157 \\
\hline bAT & $17(0.086)$ & $56(0.130)$ & $0.634(0.358-1.122)$ & 0.115 \\
\hline BAT & $8(0.040)$ & $12(0.027)$ & $1.482(0.596-3.686)$ & 0.394 \\
\hline
\end{tabular}

haplotypes with frequency $<0.03$ are ignored

research focused on this problem. However, there is research demonstrating the importance of VDR genetic variants in etiology of primary biliary cirrhosis (PBC) in different populations. The results of these investigations are inconclusive but suggest the possibility of the involvement of genetic variants in the ICP pathomechanism and their influence on liver dysfunction [29-33]. One of them is a meta-analysis of six studies ( 672 cases and 1148 total controls) showing that the VDRApal polymorphism is associated with the risk of $\mathrm{PBC}$ especially in Asians, while the VDR Taql polymorphism may affect the risk of PBC in Caucasians. However, no significant association was observed between VDRBsm/ polymorphism and PBC risk [30].

Another meta-analysis of Li et al. [31] (6 studies, 1322 subjects with PBC and 2264 controls) demonstrated that VDR Taql (rs731236) polymorphism significantly correlated with the risk of $\mathrm{PBC}$ (for allele T vs allele $\mathrm{t} O R=0.75, \mathrm{p}=0.001$; $\mathrm{TT}+\mathrm{Tt}$ vs tt $\mathrm{OR}=0.62, \mathrm{p}=0.005 ; \mathrm{OR}=0.74, \mathrm{p}=0.016$ for recessive model), while for VDR Apal (rs7975232) and VDR $B s m l$ (rs1544410) polymorphisms such correlation was not confirmed [31].

The study of 334 PBC patients (195 Japanese and 139 Italians), and 334 healthy sex- and age-matched subjects (179 Japanese and 156 Italians) showed that the BB genotype of VDR Bsm/ polymorphism was significantly associated with $\mathrm{PBC}$ risk $(\mathrm{OR}=1.80, \mathrm{p}=0.005)$, both in the Japanese $(\mathrm{OR}=13.77, \mathrm{p}=0.001)$ and Italian (OR $=1.83, \mathrm{p}=0.019)$ population, but not significantly in the Italian group after Bonferroni correction. The frequency of the VDR BsmI polymorphism $B$ allele also was significantly higher in the PBC group ( $O R=1.27, p=0.040)$, indicating the importance of both BB genotype and the B allele in PBC development [32].

In contrast, a meta-analysis performed by Mo et al. suggests that the VDR Apal, Bsml, and Taql polymorphisms do not correlate with increased risk of PBC (Apal: allele A vs allele $\mathrm{a} O R=1.132, \mathrm{p}=0.355 ; \mathrm{Bsml}$ : allele $\mathrm{B}$ vs allele $\mathrm{b}$ $\mathrm{OR}=1.148, \mathrm{p}=0.589 ;$ Taql: allele $\mathrm{t}$ vs allele $\mathrm{T} \mathrm{OR}=1.1432$, $p=0.584)$. Moreover, also in the subgroups separated by ethnicity no relationship was found between the VDR Apal, Bsml, and Taql polymorphisms and the occurrence of PBC for the Caucasian or Asian race [33].

As mentioned above, the involvement of VDR polymorphisms in ICP etiology is not fully understood, and to the best of our knowledge, this study is the first analysis of this type performed in the population of Polish women. In our study the most interesting result was the higher frequency of genotypes containing at least one mutated allele in the ICP group compared to controls. The frequency of both Ff and ff genotypes was higher in the control group of healthy women with borderline statistical significance $(p=0.045$, with $\mathrm{OR}=1.71$ ). This observation indicated the protective role of both $\mathrm{Ff}$ and ff genotypes of VDR Fokl polymorphism in ICP development. This stimulating observation indicated the direction for future research on the mechanism of ICP to prevent the clinical signs of ICP and its serious consequences for the fetus. Considering the haplotypes analysis we have not observed the significance of VDR gene haplotype settings in the etiology of ICP in Polish women. Interestingly, in our population of Polish women the most common haplotype for the VDR gene was baT, followed by BAt and bAT, as has been previously described for Caucasians [34].

A limitation of our study is the relatively small number of patients enrolled in the ICP group. On the other hand, these patients were recruited fulfilling the precise criteria for assignment to the study group including the laboratory and clinical signs of ICP. This number of subjects is not sufficient to draw definitive conclusions indicating a direct relationship between VDR polymorphic variants and ICP occurrence but shows the way for further investigations in ICP etiology. Secondly, VDR polymorphisms are unlikely to be the only variants affecting susceptibility to disease and ICP development. No less important is to identify other genetic markers in order to determine the risk groups of 
patients predisposed to the development of ICP, as well as to determine the severity of the disease and the possibility of its progression [35-38]. Finally, it is important to note that the exact pathomechanism of the impact of the presence of individual VDR polymorphic variants on ICP etiology remains unexplained. It is known that ICP etiology is multifactorial, with hormonal, genetic and environmental components. Several studies point to the possible role of vitamin $D$ in regulating steroid metabolism, as well as the importance of VDR polymorphisms for maintaining intrahepatic hemostasis. It seems crucial to identify the full ICP pathomechanism that links the presence of VDR genetic variants and serum vitamin $D$ levels to steroid metabolism, bile acid levels, and ICP prevalence. All these findings together could have important clinical implications for our patients and could improve current knowledge about the genetic determinants of ICP.

\section{CONCLUSIONS}

To our knowledge this is the first study that suggests an association between maternal VDR Fokl variant ( rs2228570) and increased risk for ICP in Polish women. This interesting observation noted in relatively small number of patients merit future research to indicate whether this relationship could modulate the ICP development.

\section{REFERENCES}

1. Bacq $Y$, Sentilhes L. Intrahepatic cholestasis of pregnancy: Diagnosis and management. Clin Liver Dis (Hoboken). 2014; 4(3): 58-61, doi: 10.1002/cld.398, indexed in Pubmed: 30992922.

2. Smith DD, Rood KM. Intrahepatic Cholestasis of Pregnancy. Clin Obstet Gynecol. 2020; 63(1): 134-151, doi: 10.1097/GRF.0000000000000495, indexed in Pubmed: 31764000.

3. Geenes V, Williamson C. Intrahepatic cholestasis of pregnancy. World J Gastroenterol. 2009; 15(17): 2049-2066, doi: 10.3748/wjg.15.2049, indexed in Pubmed: 19418576.

4. Nakagawa K, Kawaura A, Kato S, et al. 1 alpha,25-Dihydroxyvitamin $\mathrm{D}(3)$ is a preventive factor in the metastasis of lung cancer. Carcinogenesis. 2005; 26(2): 429-440, doi: 10.1093/carcin/bgh332, indexed in Pubmed: 15539405.

5. Bouillon R, Eelen G, Verlinden $L$, et al. Vitamin D and cancer. J Steroid Biochem Mol Biol. 2006; 102(1-5): 156-162, doi: 10.1016/j. jsbmb.2006.09.014, indexed in Pubmed: 17113979.

6. Wang J, Wang $\mathrm{Y}$, Han H, et al. Association of Vitamin D Receptor Gene Polymorphisms with Metabolic Syndrome in Rural Areas of China. Biomed Environ Sci. 2019; 32(4): 304-308, doi: 10.3967/bes2019.041, indexed in Pubmed: 31217067.

7. Pike JW, Meyer MB, Lee SM, et al. The vitamin D receptor: contemporary genomic approaches reveal new basic and translational insights. J Clin Invest. 2017; 127(4): 1146-1154, doi: 10.1172/JCl88887, indexed in Pubmed: 28240603.

8. Wikström Shemer E, Marschall HU. Decreased 1,25-dihydroxy vitamin D levels in women with intrahepatic cholestasis of pregnancy. Acta Obstet Gynecol Scand. 2010; 89(11): 1420-1423, doi: 10.3109/00016349.2010.515665, indexed in Pubmed: 20955096.

9. Gençosmanoğlu Türkmen G, Vural Yilmaz Z, Dağlar K, et al. Low serum vitamin $D$ level is associated with intrahepatic cholestasis of pregnancy. J Obstet Gynaecol Res. 2018; 44(9): 1712-1718, doi: 10.1111/jog.13693, indexed in Pubmed: 29978524.

10. Dror DK. Vitamin D status during pregnancy: maternal, fetal, and postnatal outcomes. Curr Opin Obstet Gynecol. 2011; 23(6): 422-426, doi: 10.1097/GCO.0b013e32834cb791, indexed in Pubmed: 21986726.
11. Gilani S, Janssen P. Maternal Vitamin D Levels During Pregnancy and Their Effects on Maternal-Fetal Outcomes: A Systematic Review. J Obstet Gynaecol Can. 2020; 42(9): 1129-1137, doi: 10.1016/j.jogc.2019.09.013, indexed in Pubmed: 31874818.

12. Lapillonne $A$. Vitamin $D$ deficiency during pregnancy may impair maternal and fetal outcomes. Med Hypotheses. 2010; 74(1): 71-75, doi: 10.1016/j.mehy.2009.07.054, indexed in Pubmed: 19692182.

13. Rizzo G, Garzon S, Fichera M, et al. Vitamin D and Gestational Diabetes Mellitus: Is There a Link? Antioxidants (Basel). 2019; 8(11), doi: 10.3390/antiox8110511, indexed in Pubmed: 31731439.

14. Gallo S, McDermid JM, Al-Nimr Rl, et al. Vitamin D Supplementation during Pregnancy: An Evidence Analysis Center Systematic Review and Meta-Analysis. J Acad Nutr Diet. 2020; 120(5): 898-924.e4, doi: 10.1016/j. jand.2019.07.002, indexed in Pubmed: 31669079.

15. Fogacci S, Fogacci F, Banach M, et al. Lipid and Blood Pressure Meta-analysis Collaboration (LBPMC) Group. Vitamin D supplementation and incident preeclampsia: A systematic review and meta-analysis of randomized clinical trials. Clin Nutr. 2020; 39(6): 1742-1752, doi: 10.1016/j. clnu.2019.08.015, indexed in Pubmed: 31526611.

16. Jefferson KK, Parikh HI, Garcia EM, et al. Relationship between vitamin D status and the vaginal microbiome during pregnancy. J Perinatol. 2019; 39(6): 824-836, doi: 10.1038/s41372-019-0343-8, indexed in Pubmed: 30858609.

17. Evans KN, Bulmer JN, Kilby MD, et al. Vitamin D and placental-decidual function. J Soc Gynecol Investig. 2004; 11(5): 263-271, doi: 10.1016/j. jsgi.2004.02.002, indexed in Pubmed: 15219879.

18. Ganguly A, Tamblyn JA, Finn-Sell S, et al. Vitamin D, the placenta and early pregnancy: effects on trophoblast function. J Endocrinol. 2018; 236(2): R93-R9R103, doi: 10.1530/JOE-17-0491, indexed in Pubmed: 29109081.

19. Norman AW. Minireview: vitamin D receptor: new assignments for an already busy receptor. Endocrinology. 2006; 147(12): 5542-5548, doi: 10.1210/en.2006-0946, indexed in Pubmed: 16946007.

20. Norman AW. From vitamin D to hormone D: fundamentals of the vitamin Dendocrine system essential for good health. Am J Clin Nutr. 2008; 88(2): 491S-499S, doi: 10.1093/ajcn/88.2.491S, indexed in Pubmed: 18689389.

21. Fan $L, T u X, Z$ hu $Y$, et al. Mechanism of vitamin $D$ receptor inhibition of cholesterol 7alpha-hydroxylase gene transcription in human hepatocytes. J Gastroenterol Hepatol. 2005; 20(2): 249-255.

22. Haussler MR, Whitfield GK, Kaneko I, et al. Molecular mechanisms of vitamin D action. Calcif Tissue Int. 2013; 92(2): 77-98, doi: 10.1007/s00223012-9619-0, indexed in Pubmed: 22782502.

23. Harris SS, Eccleshall TR, Gross C, et al. The VDR start codon polymorphism (Fok-I) and bone mineral density in premenopausal American Black and White women. J Bone Miner Res. 1997; 12: 1043-1048.

24. Morrison NA, Qi JC, Tokita A, et al. Prediction of bone density from vitamin D receptor alleles. Nature. 1994; 367(6460): 284-287, doi: 10.1038/367284a0, indexed in Pubmed: 8161378.

25. Pani MA, Knapp M, Donner $H$, et al. Vitamin D receptor allele combinations influence genetic susceptibility to type 1 diabetes in Germans. Diabetes. 2000; 49(3): 504-507, doi: 10.2337/diabetes.49.3.504, indexed in Pubmed: 10868975.

26. R Core Team R: A language and environment for statistical computing R Foundation for Statistical Computing, Vienna, Austria. 2019. https:// www.R-project.org/ (12.05.2020).

27. González JR, Armengol L, SoléX, et al. SNPassoc: an R package to perform whole genome association studies. Bioinformatics. 2007; 23(5): 644-645, doi: 10.1093/bioinformatics/btm025, indexed in Pubmed: 17267436

28. Solé $X$, Guinó $E$, Valls J, et al. SNPStats: a web tool for the analysis of association studies. Bioinformatics. 2006; 22(15): 1928-1929, doi: 10.1093/bioinformatics/btl268, indexed in Pubmed: 16720584.

29. Jones $D$, Donaldson P. Genetic factors in the pathogenesis of primary biliary cirrhosis. Clin Liver Dis. 2003; 7(4): 841-864, doi: 10.1016/s10893261(03)00095-3.

30. Fang F, Wang J, Pan J, et al. Relationship between vitamin D (1,25-dihydroxyvitamin D3) receptor gene polymorphisms and primary biliary cirrhosis risk: a meta-analysis. Genet Mol Res. 2015; 14(1): 981-988, doi: 10.4238/2015.February.6.1, indexed in Pubmed: 25730037.

31. Li Yj, Tang Yw, Shi Yq, et al. Polymorphisms in the vitamin D receptor gene and risk of primary biliary cirrhosis: a meta-analysis. J Gastroenterol Hepatol. 2014; 29(4): 706-715, doi: 10.1111/jgh.12443, indexed in Pubmed: 24224838 .

32. Tanaka A, Nezu S, Uegaki S, et al. Vitamin D receptor polymorphisms are associated with increased susceptibility to primary biliary cirrhosis in Japanese and Italian populations. J Hepatol. 2009; 50(6): 1202-1209, doi: 10.1016/j.jhep.2009.01.015, indexed in Pubmed: 19376604. 
33. Mo C, Lu Yu, Deng Y, et al. Lack of association between vitamin D receptor gene Apal, Bsml, and Taql polymorphisms and primary biliary cirrhosis risk: a meta-analysis. Tumour Biol. 2014; 35(5): 4913-4920, doi: 10.1007/s13277-014-1645-2, indexed in Pubmed: 24526415.

34. Thakkinstian A, D'Este C, Attia J. Haplotype analysis of VDR gene polymorphisms: a meta-analysis. Osteoporos Int. 2004; 15(9): 729-734, doi: 10.1007/s00198-004-1601-x, indexed in Pubmed: 15057510.

35. Floreani A, Gervasi M. New Insights on Intrahepatic Cholestasis of Pregnancy. Clin Liver Dis. 2016; 20(1):177-189, doi: 10.1016/j.cld.2015.08.010.
36. Keitel V, Dröge C, Häussinger D. Targeting FXR in Cholestasis. Handb Exp Pharmacol. 2019; 256: 299-324, doi: 10.1007/164_2019_231, indexed in Pubmed: 31201556.

37. Brady CW. Liver Disease in Pregnancy: What's New. Hepatol Commun 2020; 4(2): 145-156, doi: 10.1002/hep4.1470, indexed in Pubmed: 32025601.

38. Sticova $E$, Jirsa M. ABCB4 disease: Many faces of one gene deficiency. Ann Hepatol. 2020; 19(2): 126-133, doi: 10.1016/j.aohep.2019.09.010, indexed in Pubmed: 31759867. 